\title{
Koroner Anjiyografi ve Perkütan Transluminal Koroner Anjiyoplasti İşlemi Öncesi Uygulanan Müzik Eşliğinde Progresif Kas Gevşeme Egzersizinin Bireylerin Anksiyete Düzeylerine Olan Etkisi
}

\author{
The Effects of Progressive Relaxation Exercises Applied with Music Before \\ Coronary Angiography and Percutaneous Transluminal Coronary \\ Angioplasty on the State and Trait Anxiety of People
}

\author{
Özgür DEMIR, ${ }^{1}$ Hülya ARSLANTAŞ ${ }^{2}$
}

\section{ÖZET}

Amaç: Çalışma, koroner anjiyografi ve perkütan transluminal koroner anjiyoplasti işlemleri öncesi uygulanan müzik eşliğinde progresif kas gevşeme egzersizinin bireylerin durumluluk-süreklilik anksiyete düzeylerine olan etkisini belirlemek amacıyla yapılmıştır.

Gereç ve Yöntem: Yarı-deneysel bir araştırma olup ön test-son test, kontrol gruplu desen düzeninde uygulanmıştır. Araştırmada örneklem büyüklüğü her bir grup için 50 olarak belirlenmiş ve 50 deney koroner anjiyografi, 50 deney perkütan transluminal koroner anjiyoplasti ve 50 kontrol grubu olmak üzere toplam 150 hasta örnekleme alınmıştır. Araştırmaya katılmayı kabul eden deney ve kontrol grubundaki hastalara işlem öncesi, Kişisel Bilgi Formu, Durumluluk-Süreklilik Anksiyete Ölçeği doldurulmuştur. Bu işlemlerin tamamlanmasının ardından deney koroner anjiyografi ve deney perkütan transluminal koroner anjiyoplasti grubunda yer alan hastalara işlemden 30 dk önce müzik eşliğinde progresif kas gevşeme egzersizi uygulanmış, kontrol grubuna ise herhangi bir girişimde bulunulmamıştır. Araştırmacl, deney grubuna yapılan girişimler sırasında konuşmadan ve müdahale etmeden bireylerin yanında bulunmuştur. İşlem sonrası durumluluk-süreklilik anksiyete ölçekleri her üç gruba da işlemden $30 \mathrm{dk}$ sonra tekrar uygulanmıştır.

Bulgular: Deney koroner anjiyografi ve deney perkütan transluminal koroner anjiyoplasti grubundaki bireylerin durumluluk-süreklilik anksiyete puan ortalamaları değerlerinde, müzik eşliğinde yapılan progresif kas gevşeme egzersizi uygulaması sonrası düşüş görülmüş olup kontrol grubunun durumluluksüreklilik anksiyete puan ortalamalarında herhangi bir değişiklik olmamıştır.

Sonuç: Koroner anjiyografi ve perkütan transluminal koroner anjiyoplasti işlemi öncesi kardiyoloji servisinde müzik eşliğinde uygulanan progresif kas gevşeme egzersizinin bireylerin anksiyete düzeylerini belirgin düzeyde azaltması nedeniyle kardiyoloji servisi rutinleri içinde yer alması sağlanmalı, bu amaçla kardiyoloji servisinde primer uygulatıcılar olarak hemşireler sorumluluk almalıdırlar.

Anahtar sözcükler: Anksiyete; koroner anjiyografi; müzik dinleme; perkütan transluminal koroner anjiyoplasti; progresif kas gevşeme egzersizi.

'Dokuz Eylül Üniversitesi Hastanesi, Kardiyoloji Anabilim Dalı Kardiyoloji Servisi Hemșiresi, İzmir;

${ }^{2}$ Adnan Menderes Üniversitesi Aydın Sağlık Yüksekokulu, Ruh Sağlığı ve Hastalıkları Hemșireliği Anabilim Dalı, Aydın.

İletişim (Correspondence): Dr. Hülya ARSLANTAŞ.

e-posta (e-mail): hulyaars@yahoo.com

Psikiyatri Hemșireliği Dergisi 2014;5(3):113-121

Journal of Psychiatric Nursing 2014;5(3):113-121

Doi: $10.5505 /$ phd.2014.78942

Geliş tarihi (Submitted): 27.06.2014 Kabul tarihi (Accepted): 08.12.2014

\section{SUMMARY}

Objectives: This study was carried out to identify the effects of progressive relaxation exercise that is applied with music before coronary angiography and percutaneous transluminal angioplasty on the state and trait anxiety of people.

Methods: It is a semi-experimental investigation and preliminary test-ultimate test is designed in the control group order. The sample size was 50 for each group and it was applied to a total of 150 patients that consisted of 50 coronary angiography patients in the experimental group, 50 percutaneous trans/uminal coronary angioplasty patients in the experimental group and 50 patients in the control group. The patients taking part in the research completed a Personal Information Form and State and Trait Anxiety Scale before the procedure. After completing these forms, progressive relaxation exercise with music was applied on coronary angiography and percutaneous transluminal coronary angioplasty patients in the experimental group for 30 minutes of the process, with no therapy applied to the control group. The researcher was with the patient during the attempt that is applied on experimental group without talking or any intervention. 30 minutes later of the process, state and permanence anxiety scales are filled again by all three groups.

Results: After the progressive relaxation exercise with music, a decrease was seen on the state and trait anxiety levels of people in the coronary angiography and percutaneous transluminal coronary angioplasty experimental group members, but there was no change for control group.

Conclusion: Progressive relaxation exercise with music was applied before coronary angiography and percutaneous transluminal coronary angioplasty procedures at Cardiology Service and can decrease the anxiety levels of these individuals dramatically. We believe it must be part of the Cardiology Service routine. The nurses must be responsible for it as primary implementers.

Key words: Anxiety; coronary angiography; listening to music; percutaneous transluminal coronary angioplasty; relaxation exercises.

\section{Giriş}

Kalp hastalıklarının tıbbi ve cerrahi tedavileri önemlidir. Tedavide ilaç tedavilerinin yanında hasta için yaşam kurtarıcı ve riskleri az olan girişimsel yöntemler de kullanılmaktadır. $\mathrm{Bu}$ amaçla yaygın kullanılan girişimsel yöntemler koroner anjiyografi ve perkütan transluminal koroner anjiyoplastidir. ${ }^{[1,2]}$ Koroner anjiyografi (KAG); femoral, brakiyal, radiyal, aksillar arterlere kontrast madde verilerek sineanjiyografik olarak görüntü elde edilmesi işlemidir. ${ }^{[1,2]}$ Perkütan transluminal 
koroner anjiyoplasti (PTKA); miyokart perfüzyonunu bozacak derecede olan koroner damarlardaki darlıkların balonla açılması işlemidir. ${ }^{[1,2]}$

Koroner anjiyografi ve perkütan transluminal koroner anjiyoplasti; invazif bir tanılama yöntemi olması, kalp gibi yaşamsal önemi yüksek olan bir organın tanılanmasında kullanılması, işlemle ilgili bilinmezliklerin çok olması nedeniyle bireylerde ölüm korkusu ve buna bağlı anksiyeteye neden olur. $^{[3-5]}$

Alanyazın çalışmalarına göre; koroner anjiyografi ve perkütan transluminal koroner anjiyoplasti uygulamalarından önce bireylerin fiziksel ve duygusal gereksinimlerinin karş1lanmasının, işlem sırasında ve işlemden sonraki olumsuz sonuçların ve sedatif ilaç kullanımının azalmasına, bireyin hastanede kalma süresinin kısalmasına, iyileşme sürecinin hızlanmasına, ameliyat sonrası dönemde işleme yönelik olumlu duygular yaşanarak KAG ve PTKA işlemlerinden önce ve sonraki dönemde anksiyetenin azaltılmasında önemli olduğu belirtilmektedir. ${ }^{[6,7]}$ Bunun için kullanılan gevşeme teknikleri; meditasyon, progresif kas gevşeme, müzik dinleme, farkındalık eğitimi, yoga ve Tai Chi, ritmik egzersiz, görselleştirme meditasyonu olup gevşeme yöntemleri arasında müzik eşliğinde uygulanan progresif kas gevşeme eğitimi önemli bir yere sahiptir. ${ }^{[6,7]}$ Yapılan araştırmalarda hemşirelerin anjiyografi uygulamasında bireylerin; duygusal olarak rahatlamalarını sağlama, KAG ve PTKA işleminin tüm aşamalarında yanlarında olarak işlemle ilgili bilgilendirme, gevşeme ve solunum egzersizleri yaptırma, müzik dinletme gibi yöntemlerle bireylerin anksiyete düzeylerini azaltabilecekleri vurgulanmıştır. ${ }^{[4,8,9]}$

Sağlık bakım profesyonelleri hastanın anksiyetesinin nedenlerini ve düzeyini belirlemeye çalısmalı, hastanın anksiyetesinin azaltılması için neler yapılabileceğini tanımlamalıdırlar. Bunun için; fiziksel/tıbbi hastalığı ya da yakınması nedeniyle hastaneye başvuran hastaların ve ailelerinin sağlı̆̆ını geliştiren, primer korumadan rehabilitasyona kadar uzanan yelpazede ortaya çıkan bilişsel, psikolojik, davranışsal tepkilerini ve psikososyal sorunlarını tanımlayan konsültasyon liyezon psikiyatri hemşirelerine (KLPH) ihtiyaç vardır. Psikososyal bakımı doğrudan planlayan, uygulayan, değerlendiren ve hemşireye, ekibe, bireye, aileye danı̧̧manlık yapan, eğitim veren, kurumda psikososyal bakımın kurumsallaşmas1 için yönetime danı̧̧manlık hizmeti veren ve alanıyla ilgili araştırmalar yapan özelleşmiş bir psikiyatri hemşiresi olan KLPH dahili ve cerrrahi kliniklerinde çalışan hemşirelerle işbirliği içinde çalışmalıdır. ${ }^{[10]}$

Türkiye'de KLP hemşireliği uygulamaları çok az hastane$\mathrm{de}^{[10]}$ bulunmakta olduğu için genellikle cerrahi girişim öncesi ve sonrası hastalara sakinleşmeleri amacı ile kısa etkili anksiyolitikler uygulanmaktadır. ${ }^{[6,11]}$ Oysa müzik eşliğinde yapılan kas gevşeme egzersizi ile hastaların böyle bir gereksinime ihtiyacı olmadığı görülmektedir. Ülkemizde cerrahi girişimler öncesi rutin olarak uygulanan müzik eşliğinde kas gevşeme egzersizi uygulaması ve standardı olmadığ 1 için bu çalışmayla böyle bir standardın oluşturulması için adım atılması planlanmıştır.

$\mathrm{Bu}$ çalışma, koroner anjiyografi ve perkütan transluminal koroner anjiyoplasti işlemleri öncesi uygulanan müzik eşliğinde progresif kas gevșeme egzersizinin bireylerin durumluluk-süreklilik anksiyete düzeyleri üzerine etkisini belirlemek amacı ile yapılmıştır.

Araştırma sorusu; Koroner anjiyografi ve perkütan transluminal koroner anjiyoplasti işlemleri öncesi uygulanan müzik eşliğinde progresif kas gevşeme egzersizinin bireylerin durumluluk ve süreklilik anksiyete düzeyleri üzerine etkisi var midir?

\section{Gereç ve Yöntem}

\section{Araştırmanın Evreni ve Örneklemi}

Araştırma Dokuz Eylül Üniversitesi Araştırma ve Uygulama Hastanesi Kardiyoloji Servisi'nde 2012-2013 y1llar1 arasinda yatmakta olan KAG, PTKA ve kontrol grubu hastalarında yapılmıştır. Bu yıllar arasında hastanede 3000 hasta KAG ve PTKA işlemine tabi tutulmuştur. Örneklem sayısı G-Power analiz programına göre her bir grup için 50 olarak belirlenmiş olup toplam 150 hasta örnekleme alınmıştır. Araştırma ön test-son test, kontrol gruplu desen düzeninde gerçekleştirilmiştir. Kura yöntemi ile ayın tek günleri kontrol grubu, çift günleri ise deney KAG ve PTKA grubunun çalı̧̧maya alınmasına karar verilmiştir. Her üç grubun seçiminde araştırma ve uygulamanın güvenilir olması açısından yaş, cinsiyet ve eğitim durumu gibi bireysel özelliklerin benzer olmasına özen gösterilmiştir. Örnekleme alınan bireylerin tamamı araştırmaya katılmayı kabul etmiş olup, bireylere bilgilendirilmiş gönüllü onam formu doldurulmuştur. Hastaların araştırmaya alınma kriterleri; daha önce KAG ve PTKA işlemi uygulanmamış olma, 18 yaşından büyük olma, bilinç açık, oryante ve koopere olma, anksiyete belirtilerini baskılayacak herhangi bir analjezik ya da anksiyolitik ilaç almamış olma, çalışmaya katılmaya istekli olma, araştırmadan dışlanma kriterleri ise; iletişimi engelleyecek düzeyde görme problemi olması, zihinsel işlevlerinde yetersizlik olması, işitme sorunu olması olarak belirlenmiştir.

\section{Deneysel Uygulama}

Çalışmaya katılmayı kabul eden, araştırmaya alınma ölçütlerine uygun olan KAG ve PTKA hastalarına uygulama öncesi araştırma ile ilgili açıklama yapıldıktan sonra sözel ve yazılı onamları alınmıştır. "Kişisel Bilgi Formu" uygulanarak yaş, cinsiyet, meslek, eğitim durumu ve medeni durumları öğrenilmiştir. Bireylere "Durumluluk ve Süreklilik Anksiyete 
Ölçeği” yüz yüze görüşme yöntemi ile doldurulmuştur. $\mathrm{Bu}$ işlemlerin tamamlanmasının ardından deney KAG ve deney PTKA grubunda yer alan hastalar işlemden $30 \mathrm{dk}$ önce kardiyoloji servisinde sessiz, temiz ve iyi aydınlatılmış bir odaya alınmıştır. Progresif gevşeme tekniklerinin öğretilmesi için Türk Psikologlar Derneği Progresif Kas Gevşeme Egzersizi (PGE) CD'si ${ }^{[12]}$ dinletilip gerekli açıklamalar yapıldıktan sonra araştırmacı tarafından kasetteki egzersizler yaptırılmı̧̧tir.

Bireyler arasındaki bireysel farklılıklar göz önüne alınarak gerektiğinde tekrarlar yapılmış, soruları yanıtlanmış ve endişelerini paylaşmaları için firsat verilmiştir. Daha sonra uzanır pozisyonda bireylere, rahat bir pozisyon almaları, müzik eşliğinde verilen gevşeme egzersizini yapmaları, işlemin sonucunun olumlu olacağını hayal etmeleri söylenmiştir ve kulaklık yoluyla PGE CD'si dinletilmeye başlatılip, isterlerse CD'nin sesine müdahale edebilecekleri; sesi açıp kapatabilecekleri, CD'yi durdurabilecekleri ve yeniden dinlemeye başlayabilecekleri iletilmiştir. Çalışmacı, bu süre içinde bireyin yanında konuşmadan ve müdahale etmeden bulunmuştur. Uygulama tamamlandıktan sonra araştırmacı bireyin kulaklığını çıkararak ameliyat önlügünü giymesine yardım etmiş ve servis hemşiresi tarafindan damar yolu açılarak anjiyo salonuna gönderilmiştir. Uygulamadan $30 \mathrm{dk}$ sonra hasta odasında bireylere "Durumluluk-Süreklilik Anksiyete Ölçeği” yüz yüze görüşme yöntemiyle tekrar uygulanmıştır.

Kontrol grubundaki hastalara işlemden $30 \mathrm{dk}$ önce "Kişisel Bilgi Formu" ve "Durumluluk-Süreklilik Anksiyete Ölçeği” uygulanmış ve araştırmacı hastanın yanından ayrılmıştır. İşlemden $30 \mathrm{dk}$ sonra ise durumluluk-süreklilik anksiyete ölçeği yüz yüze görüşme yöntemiyle doldurulmuştur.

Her üç gruba da çalışmanın amacı açıklanarak sözel ve yazılı onamları alınmış olup, işlem öncesi herhangi bir farmakolojik tedavi uygulanmamıştır.

\section{Kullanılan Araçlar}

Araştırmada araştırmacının hazırladığı "Kişisel Bilgi Formu", "Durumluluk ve Süreklilik Anksiyete Ölçeği” kullanımıştır. "Kişisel Bilgi Formu" araştırmacılar tarafından alanyazın çalışmalarının taranması ${ }^{[8,11]}$ sonucunda "Durumluluk ve Süreklilik Anksiyete Ölçeği” puanını en çok etkileyeceği düşünülen yaş, cinsiyet, meslek, eğitim ve medeni durum gibi bireysel özelliklerini kapsayan toplam beş sorudan oluşmuştur.

Durumluluk Anksiyete Ölçeği (State Anxiety Scale); Bireylerin durumluluk kayg1 düzeylerini saptamak amacıyla Spielberger ve ark. tarafından 1970 yılında geliştirilmiş ve Türkiye'de Öner (1985) tarafindan geçerlilik güvenilirlik çalışması yapılmış olan ölçek 20 maddeden oluşmaktadır. On dört yaş üstü bireylere uygulanabilmektedir. Katılımc1- lar, ölçekte yer alan her bir ifade için "hemen hiçbir zaman", "bazen", “çoğu zaman” ya da "hemen her zaman" seçeneklerinden kendilerine en uygun olanı işaretlemektedir. Durumluluk Kayg1 ölçeğinde on tane tersine dönmüş ifade vardır. Durumluluk Kayg1 ölçeğinde, 20 maddenin değerlendirilmesi yapilırken 3, 4, 6, 7, 9, 12, 13, 14, 17, 18. maddeler için pozitif (toplam kaygı puanını arttıran), kalan maddeler içinse negatif (toplam kayg1 puanını azaltan) puanlar verilmektedir. Değerlendirmede, her madde için 1 ile 4 arasında bir puan verilmektedir. Ölçekten elde edilebilecek en yüksek puan 80, en düşük puan ise 20'dir. Hesaplanan toplam kaygı puanı ne kadar yüksekse ölçeği dolduran kişinin kaygı düzeyi o kadar fazladır. ${ }^{[13]}$

Süreklilik Anksiyete Ölçeği (Trait Anxiety Scale); Bireylerin süreklilik kaygı düzeylerini saptamak amaciyla Spielberger ve arkadaşları tarafindan 1970 yılında geliştirilmiş ve Türkiye'de Öner (1985) tarafından geçerlilik güvenilirlik çalışması yapılmış olan ölçek 20 maddeden oluşmaktadır. Süreklilik kaygı ölçeğinin yanıtlanmasında maddelerin ifade ettiği duyuş, düşünce ya da davranışların sıklık derecesine göre "hemen hiçbir zaman”, "bazen”, "çok zaman” ve "hemen her zaman" seçeneklerinden birinin işaretlenmesi istenir. Toplam 20 maddeden oluşmaktadır. Bu bölümde yedi tane tersine dönmüş ifade bulunmakta olup bunlar: 21, 26, 27, 30, 33, 36, 39 maddeleridir. ${ }^{[13]}$

\section{Araştırmanın Etik Boyutu}

Araştırma için Dokuz Eylül Üniversitesi Girişimsel olmayan Araştırmalar Etik Kurulundan etik kurul onayı alınmıştır.

\section{Veri Analizi}

Çalışmadan elde edilen veriler, SPSS 15.0 programı kullanılarak analiz edilmiştir. Çalışma verileri değerlendirilirken tanımlayıc1 istatistiksel yöntemlerin (Yüzdelik hesaplamalar, Ortanca, Ortalama, Standart sapma) yanı sıra tekrarlı ölçümlerde Varyans Analizi ve One Way Anova testi kullanılmışıtır. Araştırmanın bağımlı değişkenleri hastaların durumluluksüreklilik anksiyete ölçeği puanları, bağımsız değişkenleri ise hastaların sosyo demografik özelliklerine ilişkin sorulardır. Sonuçlar \%95'lik güven aralığında, anlamlılık p<0.05 düzeyinde değerlendirilmiştir.

\section{Bulgular}

Deney KAG grubundaki bireylerin \%72'sinin ( $\mathrm{n}=36)$ erkek; \%64'ünün $(n=32) 18-64$ yaş arası; \%92'sinin $(n=46)$ evli; \%36'sinın ( $\mathrm{n}=18)$ ilkokul mezunu; \%70'inin $(\mathrm{n}=35)$ emekli olduğu bulunmuştur. Deney PTKA grubundaki bireylerin $\% 62$ 'sinin $(n=31)$ erkek; \%60'ının ( $n=30) 65$ yaş ve üstünde; \%86'sinın ( $n=43)$ evli; \%46'sinın ( $n=23)$ ilkokul mezunu; $\% 72$ 'sinin $(\mathrm{n}=36)$ emekli olduğu bulunmuştur. Kontrol grubundaki bireylerin \%64'ünün ( $\mathrm{n}=32)$ erkek; \%68'inin ( $\mathrm{n}=34)$ 
Tablo 1. Deney ve kontrol grubundaki bireylerin kișisel özelliklerinin karșılaștırılması

\begin{tabular}{|c|c|c|c|c|c|c|c|c|}
\hline \multirow[t]{2}{*}{ Bireysel özellikler } & \multicolumn{2}{|c|}{$\begin{array}{l}\text { Deney KAG grubu } \\
\qquad(n=50)\end{array}$} & \multicolumn{2}{|c|}{$\begin{array}{l}\text { Deney PTKA grubu } \\
\qquad(n=50)\end{array}$} & \multicolumn{2}{|c|}{$\begin{array}{l}\text { Kontrol grubu } \\
(n=50)\end{array}$} & \multicolumn{2}{|c|}{$\begin{array}{l}\text { İstatistiksel } \\
\text { değerlendirme }\end{array}$} \\
\hline & $n$ & $\%$ & $\mathrm{n}$ & $\%$ & $\mathrm{n}$ & $\%$ & $\mathrm{X}^{2}$ & $\mathrm{p}$ \\
\hline \multicolumn{9}{|l|}{ Cinsiyet } \\
\hline Kadin & 14 & 28.0 & 19 & 38.0 & 18 & 36.0 & 1.248 & 0.535 \\
\hline Erkek & 36 & 72.0 & 31 & 62.0 & 32 & 64.0 & & \\
\hline \multicolumn{9}{|l|}{ Yaș } \\
\hline $18-64$ & 32 & 64.0 & 20 & 40.0 & 34 & 68.0 & 9.37 & $0.009^{*}$ \\
\hline 65 ve üstü & 18 & 36.0 & 30 & 60.0 & 16 & 32.0 & & \\
\hline \multicolumn{9}{|l|}{ Medeni durum } \\
\hline Bekâr & 1 & 2.0 & 0 & 0.0 & 1 & 2.0 & 4.69 & 0.32 \\
\hline Evli & 46 & 92.0 & 43 & 86.0 & 47 & 94.0 & & \\
\hline Dul & 3 & 6.0 & 7 & 14.0 & 2 & 4.0 & & \\
\hline \multicolumn{9}{|l|}{ Eğitim } \\
\hline ilkokul & 18 & 36.0 & 23 & 46.0 & 25 & 50.0 & 5.57 & 0.473 \\
\hline Ortaokul & 7 & 14.0 & 7 & 14.0 & 3 & 6.0 & & \\
\hline Lise & 13 & 26.0 & 14 & 28.0 & 11 & 22.0 & & \\
\hline Üniversite ve üstü & 12 & 24.0 & 6 & 12.0 & 11 & 22.0 & & \\
\hline \multicolumn{9}{|l|}{ Meslek } \\
\hline İșçi & 2 & 4.0 & 1 & 2.0 & 2 & 4.0 & 9.87 & 0.274 \\
\hline Memur & 3 & 6.0 & 2 & 40.0 & 5 & 10.0 & & \\
\hline Emekli & 35 & 70.0 & 36 & 72.0 & 31 & 62.0 & & \\
\hline Çiftçi & 0 & 0.0 & 1 & 2.0 & 5 & 10.0 & & \\
\hline Diğer & 10 & 20.0 & 10 & 20.0 & 7 & 14.0 & & \\
\hline
\end{tabular}

" $\mathrm{p}<0.01$; KAG: Koroner anjiyografi; PTKA: Perkütan transluminal koroner anjiyoplasti.

18-64 yaş arasında; \%94'ünün ( $\mathrm{n}=47)$ evli; \%50'sinin ( $\mathrm{n}=25)$ ilkokul mezunu; \%62'sinin ( $\mathrm{n}=31$ ) emekli olduğu bulunmuştur (Tablo 1).
Araştırmamızda her üç grup arasında yaş $(\mathrm{p}=0.009)$ bireysel özelliği dışında diğer bireysel özellikler açısından istatistiksel olarak anlamlı bir fark yoktur ( $>$ >0.05) (Tablo 1).

Tablo 2. Deney ve kontrol grubundaki bireylerin bireysel özelliklerine göre uygulama öncesi ve sonrası durumluluk anksiyete puanının karșılaștırılması

\begin{tabular}{|c|c|c|c|c|c|c|c|c|c|c|}
\hline \multirow{3}{*}{$\begin{array}{l}\text { Durumluluk kaygı } \\
\text { Bireysel özellikler }\end{array}$} & \multicolumn{6}{|c|}{ Gruplar } & \multicolumn{4}{|c|}{ İstatistiksel değerlendirme } \\
\hline & \multicolumn{2}{|c|}{$\begin{array}{c}\text { Deney KAG } \\
(n=50)\end{array}$} & \multicolumn{2}{|c|}{$\begin{array}{c}\text { Deney PTKA } \\
(n=50)\end{array}$} & \multicolumn{2}{|c|}{$\begin{array}{c}\text { Kontrol } \\
(n=50)\end{array}$} & \multicolumn{2}{|c|}{$\mathbf{F}$} & \multicolumn{2}{|c|}{$\mathrm{p}$} \\
\hline & $n$ & $\%$ & $\mathrm{n}$ & $\%$ & $\mathrm{n}$ & $\%$ & UÖ & US & UÖ & US \\
\hline \multicolumn{11}{|l|}{ Cinsiyet } \\
\hline Kadın & 14 & 28.0 & 19 & 38.0 & 18 & 36.0 & 1.904 & 0.233 & 0.153 & 0.792 \\
\hline Erkek & 36 & 72.0 & 31 & 62.0 & 32 & 64.0 & & & & \\
\hline \multicolumn{11}{|l|}{ Yaș } \\
\hline $18-64$ & 32 & 64.0 & 20 & 40.0 & 34 & 68.0 & 0.025 & 0.943 & 0.975 & 0.392 \\
\hline 65 ve üstü & 18 & 36.0 & 30 & 60.0 & 16 & 32.0 & & & & \\
\hline \multicolumn{11}{|l|}{ Medeni durum } \\
\hline Bekâr & 1 & 2.0 & 0 & 0.0 & 1 & 2.0 & 1.282 & 0.011 & 0.283 & 0.998 \\
\hline Evli & 46 & 92.0 & 43 & 86.0 & 47 & 94.0 & & & & \\
\hline Dul & 3 & 6.0 & 7 & 14.0 & 2 & 4.0 & & & & \\
\hline \multicolumn{11}{|l|}{ Eğitim } \\
\hline Ilkokul & 18 & 36.0 & 23 & 46.0 & 25 & 50.0 & 0.691 & 0.918 & 0.657 & 0.484 \\
\hline Ortaokul & 7 & 14.0 & 7 & 14.0 & 3 & 6.0 & & & & \\
\hline Lise & 13 & 26.0 & 14 & 28.0 & 11 & 22.0 & & & & \\
\hline Üniversite ve üstü & 12 & 24.0 & 6 & 12.0 & 11 & 22.0 & & & & \\
\hline \multicolumn{11}{|l|}{ Meslek } \\
\hline İșçi & 2 & 4.0 & 1 & 2.0 & 2 & 4.0 & 0.364 & 1.014 & 0.922 & 0.424 \\
\hline Memur & 3 & 6.0 & 2 & 4.0 & 5 & 10.0 & & & & \\
\hline Emekli & 35 & 70.0 & 36 & 72.0 & 31 & 62.0 & & & & \\
\hline Çiftçi & 0 & 0.0 & 1 & 2.0 & 5 & 10.0 & & & & \\
\hline Diğer & 10 & 20.0 & 10 & 20.0 & 7 & 14.0 & & & & \\
\hline
\end{tabular}

KAG: Koroner anjiyografi; PTKA: Perkütan transluminal koroner anjiyoplasti. 
Araştırmamızda; her üç grup arasında bireysel özellikler açısından uygulama öncesi ve uygulama sonrası durumluluk kayg1 puanlarında istatistiksel olarak bir anlamlilık bulunmamıştır ( $p>0.05)$ (Tablo 2).

Araştırmamızda her üç grup arasında bireysel özellikler açısından uygulama öncesi ve sonrası süreklilik anksiyete puanları açısından istatistiksel olarak bir anlamlılık bulunmamıştır ( $>$ >0.05) (Tablo 3).

Deney ve kontrol grubundaki bireylerin uygulama öncesi ve sonrası durumluluk kaygı puan ortalamalarının dağılımı Tablo 4'de verilmiştir. Bireylerin girişim öncesi durumluluk kayg1 puan ortalamaları arasında istatistiksel olarak anlamlı bir fark bulunmamışken, girişim sonrası durumluluk kaygı puan ortalamalarının istatistiksel açıdan anlamlı olduğu bulunmuştur $(\mathrm{F}=0.152 ; \mathrm{p}=0.000)$. Bu farkın hangi gruptan kaynaklandığını saptamak amacıyla ileri analiz için Tukey HSD yapılmıştır. İleri analiz sonucunda farkın durumluluk kaygı puan ortalaması $(52.86 \pm 10.00)$ yüksek olan kontrol grubundan kaynaklandığı bulunmuştur.

Deney ve kontrol grubundaki bireylerin uygulama öncesi ve sonrası süreklilik kaygı puan ortalamalarının dağılımı Tablo 5 'te verilmiştir. Bireylerin girişim öncesi sürekli kayg1 puan ortalamaları arasında istatistiksel açıdan anlamlı bir fark bulunmamıştır. Uygulama sonrası bireylerin sürekli kaygı puan ortalamalarının $\mathrm{p}<0.05$ düzeyinde anlamlı olduğu bulunmuş-
$\operatorname{tur}(\mathrm{F}=3.24 ; \mathrm{p}=0.042)$. Bu farkın hangi gruptan kaynaklandığını saptamak amacıyla yapılan ileri analizde Tukey HSD kullanılmışır. İleri analiz sonucunda farkın süreklilik kaygı puan ortalaması yüksek olan kontrol grubundan kaynaklandığ 1 bulunmuştur.

\section{Tartışma}

$\mathrm{Bu}$ araştırma koroner anjiyografi ve perkütan transluminal koroner anjiyoplasti işlemi öncesi uygulanan müzik eşliğinde kas gevşeme egzersizinin bireylerin anksiyete düzeylerine olan etkisini belirlemek amacıyla yapılmıştır.

Her üç gruptaki bireylerin çoğunun erkek olduğu görülmektedir. KAH'nin en fazla erkeklerde görüldüğü bildirilmektedir. ${ }^{[14]} \mathrm{KAH}$ ile ilgili yapılan çalışmalarda da erkek hasta sayısının yüksek olduğu bulunmuştur. ${ }^{[15,16]}$ Fitzsimons ve ark. (2003) çalıştığı KAH hastalarının \%84'ünü, Doering ve ark. (2000) \%79'unu erkek hastaların oluşturduğunu bulmuş olup; bizim çalı̧̧ma bulgumuz ile bu çalı̧̧malar arasında cinsiyet açısından bir paralellik vardır. ${ }^{[3,16]}$

Araştırmaya alınan bireylerin tamamına yakınının evli olduğu görülmektedir. Literatürde tanı ve tedaviye uyumda sağlık profesyonellerinin yanı sıra aile ve özellikle eş desteğinin önemli olduğu vurgulanmakta, bireylerin kaygilarını öncelikle aileleriyle paylaştıkları, bunun da anksiyete düzeyini ve işlemin tercih edilme olasılığını etkileyebileceği belirtilmektedir. ${ }^{[17,18]}$

Tablo 3. Deney ve kontrol grubundaki bireylerin bireysel özelliklerine göre uygulama öncesi ve sonrası süreklilik anksiyete puanının karșılaștırılması

\begin{tabular}{|c|c|c|c|c|c|c|c|c|c|c|}
\hline \multirow{3}{*}{$\begin{array}{l}\text { Süreklilik kaygı } \\
\text { Bireysel özellikler }\end{array}$} & \multicolumn{6}{|c|}{ Gruplar } & \multicolumn{4}{|c|}{ İstatistiksel değerlendirme } \\
\hline & \multicolumn{2}{|c|}{$\begin{array}{c}\text { Deney KAG } \\
(n=50)\end{array}$} & \multicolumn{2}{|c|}{$\begin{array}{c}\text { Deney PTKA } \\
(n=50)\end{array}$} & \multicolumn{2}{|c|}{$\begin{array}{c}\text { Kontrol } \\
(n=50)\end{array}$} & \multicolumn{2}{|c|}{$\mathbf{F}$} & \multicolumn{2}{|c|}{$\mathrm{p}$} \\
\hline & $\mathrm{n}$ & $\%$ & $\mathrm{n}$ & $\%$ & $\mathrm{n}$ & $\%$ & บÖ & US & บÖ & US \\
\hline \multicolumn{11}{|l|}{ Cinsiyet } \\
\hline Kadın & 14 & 28.0 & 19 & 38.0 & 18 & 36.0 & 0.026 & 0.214 & 0.974 & 0.808 \\
\hline Erkek & 36 & 72.0 & 31 & 62.0 & 32 & 64.0 & & & & \\
\hline \multicolumn{11}{|l|}{ Yaș } \\
\hline $18-64$ & 32 & 64.0 & 20 & 40.0 & 34 & 68.0 & 0.137 & 0.914 & 0.873 & 0.403 \\
\hline 65 ve üstü & 18 & 36.0 & 30 & 60.0 & 16 & 32.0 & & & & \\
\hline \multicolumn{11}{|l|}{ Medeni durum } \\
\hline Bekâr & 1 & 2.0 & 0 & 0.0 & 1 & 2.0 & 1.591 & 0.610 & 0.194 & 0.609 \\
\hline Evli & 46 & 92.0 & 43 & 86.0 & 47 & 94.0 & & & & \\
\hline Dul & 3 & 6.0 & 7 & 14.0 & 2 & 4.0 & & & & \\
\hline \multicolumn{11}{|l|}{ Eğitim } \\
\hline ilkokul & 18 & 36.0 & 23 & 46.0 & 25 & 50.0 & 1.421 & 1.225 & 0.211 & 0.297 \\
\hline Ortaokul & 7 & 14.0 & 7 & 14.0 & 3 & 6.0 & & & & \\
\hline Lise & 13 & 26.0 & 14 & 28.0 & 11 & 22.0 & & & & \\
\hline Üniversite ve üstü & 12 & 24.0 & 6 & 12.0 & 11 & 22.0 & & & & \\
\hline \multicolumn{11}{|l|}{ Mesleği } \\
\hline İşçi & 2 & 4.0 & 1 & 2.0 & 2 & 4.0 & 0.643 & 1.407 & 0.720 & 0.207 \\
\hline Memur & 3 & 6.0 & 2 & 4.0 & 5 & 10.0 & & & & \\
\hline Emekli & 35 & 70.0 & 36 & 72.0 & 31 & 62.0 & & & & \\
\hline Çiftçi & 0 & 0.0 & 1 & 2.0 & 5 & 10.0 & & & & \\
\hline Diğer & 10 & 20.0 & 10 & 20.0 & 7 & 14.0 & & & & \\
\hline
\end{tabular}

KAG: Koroner anjiyografi; PTKA: Perkütan transluminal koroner anjiyoplasti. 
Tablo 4. Deney ve kontrol grubundaki bireylerin uygulama öncesi ve sonrası durumluluk anksiyete puan ortalamalarının dağılımı

\begin{tabular}{lcccccc}
\hline Durumluluk anksiyete & \multicolumn{3}{c}{ Gruplar } & & $F$ & P \\
\cline { 2 - 4 } \cline { 3 - 4 } & $\begin{array}{c}\text { Deney KAG } \\
(n=50)\end{array}$ & $\begin{array}{c}\text { Deney PTKA } \\
(n=50)\end{array}$ & $\begin{array}{c}\text { Kontrol } \\
(n=50)\end{array}$ & & \\
\hline Uygulama öncesi (Ort. $\pm S S)$ & $56.54 \pm 9.10$ & $57.44 \pm 7.27$ & $56.50 \pm 11.96$ & & 0.152 & 0.859 \\
Uygulama sonrasi (Ort. \pm SS) & $33.00 \pm 6.49$ & $35 \pm 8.64$ & $52.86 \pm 10.00$ & & 79.715 & $0.000^{*}$ \\
\hline
\end{tabular}

*p<0.001; KAG: Koroner anjiyografi; PTKA: Perkütan transluminal koroner anjiyoplasti; Ort.: Ortalama; SS: Standart sapma.

Tablo 5. Deney ve kontrol grubundaki bireylerin uygulama öncesi ve sonrası süreklilik anksiyete puan ortalamalarının dağılımı

\begin{tabular}{|c|c|c|c|c|c|}
\hline \multirow[t]{2}{*}{ Süreklilik kaygı } & \multicolumn{3}{|c|}{ Gruplar } & \multirow[t]{2}{*}{$F$} & \multirow[t]{2}{*}{$\mathrm{p}$} \\
\hline & $\begin{array}{c}\text { Deney KAG } \\
(n=50)\end{array}$ & $\begin{array}{c}\text { Deney PTKA } \\
(n=50)\end{array}$ & $\begin{array}{c}\text { Kontrol } \\
(n=50)\end{array}$ & & \\
\hline Uygulama öncesi (Ort. $\pm S S$ ) & $49.86 \pm 8.38$ & $53.16 \pm 6.83$ & $50.76 \pm 9.39$ & 2.125 & 0.123 \\
\hline Uygulama sonrası (Ort. \pm SS) & $50.26 \pm 8.48$ & $54.20 \pm 6.30$ & $52.14 \pm 8.22$ & 3.24 & $0.042^{*}$ \\
\hline
\end{tabular}

* $p<0.05$; KAG: Koroner anjiyografi; PTKA: Perkütan transluminal koroner anjiyoplasti; Ort.: Ortalama; SS: Standart sapma.

Çalışmamızda her üç gruptaki bireylerin eğitim durumlarının benzerlik gösterdiği, bireylerinin çoğunluğunun ilkokul mezunu olduğu saptanmıştır. Bu bulgular çalışmaya alınan bireylerin homojen olduğunu yansıtmaktadır. Ayrıca bu bulgu ülkemizdeki eğitim profiline de uygundur. ${ }^{[19]}$

Araştırmamızda her üç grup arasında yaş bireysel özelliği dışında diğer bireysel özellikler açısından anlamlılık yoktur. Bu bulgu araştırmaya katılan bireylerin bireysel özelliklerinin birbirine benzer olması açısından önemlidir. Bu durum deney ve kontrol grubundaki bireylerin birbirlerine benzediğini ve homojen olduğunu göstermektedir. Bu da araştırma müdahalesinin yanlılığını azaltmakta ve sonuçların güvenilirliğini artırmaktadır. Yaştaki anlamlılığın nedeni olarak ise değişen teknoloji dolayısıyla KAG ve PTKA uygulamasına artık 18 yaşından itibaren bireylerin alınmaya başlanmasından kaynaklandığı düşünülmektedir. Çünkü kliniğimizde hastalardaki kalp hastalığını atlamamak için en ufak bir göğüs ağrisında ya da KAH'yi düşündürecek bir belirtide KAG ve PTKA işlemi uygulanmaktadır.

Araştırmada her üç grup arasında bireysel özellikler açısından uygulama öncesi ve sonrası durumluluk ve süreklilik anksiyete puanlarında istatistiksel olarak bir anlamlılık bulunmamıştır. Araştırmamıza benzer şekilde Bal'ın (2002) araştırmasında $\mathrm{da}$, bireylerin işlem öncesi anksiyete puan ortalamalarına bakıldığında, yüksekokul ve üniversite mezunlarının düşük anksiyeteye sahip oldukları görülmüş ancak eğitim düzeyine göre istatistiki açıdan anlamlı bir fark bulunmamıştır. ${ }^{[20]}$ Bireysel özellikleri ne olursa olsun, bireyin kendisini tehdit eden herhangi bir durum karşısında anksiyete yaşadığ ${ }_{1}^{[9,17]}$ dolayısıyla hemşirelerin girişim ünitesine ge- len tüm hastaların anksiyetesini belirleyip, gerekli hemşirelik yaklaşımını göstermeleri gerektiği söylenebilir.

Çalışmamızda diğer bazı çalışmalara benzer şekilde meslek ile anksiyete puanları arasında anlamlı bir ilişki bulunmamıştır. ${ }^{[21,22]}$ Aynı şekilde cinsiyet ile anksiyete puanları arasında da anlamlı bir ilişki bulunmamıştır. Bulgularımızın tersine Akdağ (2001), Dereli (1992) ve Günaydın’ın (1998) yapmış oldukları çalışmalarda kadınların erkeklere oranla kaygı düzeyleri daha yüksek bulunmuştur. ${ }^{[23-25]}$

Koca'nın (1998) yapmış olduğu çalı̧̧mada durumluluk ve süreklilik kayg1 düzeyleri evlilerde daha yüksek bulunmuşken, Güneş'in (2001) yapmış olduğu çalışmada evli bireylerin durumluluk-süreklilik kaygı düzeyleri daha düşük bulunmuştur. [26,27] Uzun ve ark.nın (2008) koroner anjiyografi işlemi olacak 88 hastayla yaptıkları çalışmada da süreklilik kaygı düzeyinin kadın hastalarda daha yüksek olduğu bildirilmiştir. ${ }^{[28]}$

Qasimi (2007) endoskopi işlemi uygulanacak 61 hastayla yaptığ anksiyete puan ortalamalarını karşılaştırdığında, sadece yaş bireysel özelliği ile durumluluk anksiyete puan ortalamaları arasında istatistiksel olarak anlamlı bir fark bulmuştur. ${ }^{[29]}$

Gökdoğan (1989) endoskopi öncesi hastalarda oluşan anksiyeteye eğitimin etkilerinin ölçülmesi ve değerlendirilmesi amacıyla yapmış olduğu çalı̧̧mada, sürekli anksiyete puan ortalaması, okuma-yazma bilmeyen ile okuma-yazma bilen grupta, orta ile yükseköğrenim düzeyinde eğitim alan gruba göre daha yüksek bulmuştur. ${ }^{[30]}$

Bireylerin uygulama öncesi durumluluk anksiyete puan ortalamaları arasında istatistiksel olarak anlamlı bir fark bu- 
lunmamışken, uygulama sonrası durumluluk anksiyete puan ortalamaları arasında istatistiksel açıdan ileri düzeyde anlam11 bir ilişki bulunmuştur (Tablo 4).

Koroner anjiyografi ve PTKA invazif bir tanılama yöntemi olup ağr1, bilinmezlik korkusunun yanı sıra, kalp gibi yaşamsal önemi olan bir organla ilgili olması, ölümü anımsatan bir hastalı̆̆ $1 \mathrm{KAH})$ araştırmaya yönelik olması bu nedenle de olumsuz bir sonuçla karşılaşma olasılığının bulunması sorunlarını içeren kaygı verici bir uygulamadır. ${ }^{[28]}$ Bireylerin uygulama öncesi anksiyete düzeylerinin yüksek olması bu durumlarla ilişkilendirilebilir.

Koroner arter hastalarında anksiyete ve depresyonun etkilerinin incelendiği bir çalışmada; akut kardiyak sorun yaşayan hastalarda anksiyetenin yaygın olarak görüldüğü, miyokart enfarktüsünden (ME) sonra mortalite riskinin üç kat fazla olduğu, beş yıldan sonra tekrar enfarktüs geçirme riskinin iki kat fazla olduğu ve ani kardiyak ölüm riskinin arttığ 1 belirlenmiştir. ${ }^{[31]}$ Yine bu hastalarda majör depresyon insidansının yaklaşık \%25 olduğu ve ME'den sonra ortaya çıkan majör depresyonun hem yaşam kalitesi hem de sürdürülen tedavi ve terapiler üzerinde olumsuz etkileri olduğu ve mortalite riskini dört kat artırdığ 1 belirtilmektedir. ${ }^{[32]} \mathrm{Bu}$ çalışma araştırmamızın sonucu ile paralellik göstermektedir. Alan yazında invazif girişimler öncesi anksiyete düzeyleri yüksek olan hastaların girişim sırasında kan basıncı değerlerinin yükseldiği, daha fazla anestetik madde kullanılması gerektiği ve \%53'ünde anksiyeteye bağlı komplikasyonların geliştiği belirtilmektedir. ${ }^{[33]}$

Cerrahi girişim uygulanan hastaların ağrı ve anksiyete nedeniyle yaşadıkları bu sorunlar ve komplikasyonlar onların gereksinimleri doğrultusunda hazırlanan bakım planı ve uyumlu ekip çalışması ile en aza indirilebilir. Hastane ortamında sürekli olarak hastayla iletişim içinde olması nedeniyle bu bakımı sağlayacak en uygun kişi hemşiredir. İnvaziv tanı işlemleri öncesi hastanın fiziksel ve psikolojik hazırlık ve bakımı ile hasta eğitimini içeren nitelikli bir bakımın girişimden sonra iyileşmeyi hızlandıracağı ve olası komplikasyonları önleyeceği düşünülmektedir. ${ }^{[34]}$

Anksiyete bireyde kalp hızını, kan basıncını, vücut 1sıs1nı ve solunum hızını yükselten, kişinin ağrı eşiğini düşüren ve buna bağlı işlem sonrası analjezik gereksinimini artıran ve komplikasyon gelişme sonuçları olan bir sorundur. ${ }^{[6,7]} \mathrm{Bu}$ doğrultuda yapılan çalı̧̧malar müzik eşliğinde yapılan gevşeme egzersizinin anksiyete ve ağrı üzerinde olumlu etkiler yarattığını, hasta veya sağlıklı bireylerin yaşam kalitesini yükselttiğini göstermiştir. ${ }^{[4,35]}$

Koroner anjiyografi işlemi ile ilgili olarak çalışmamıza benzer bir çalışmaya rastlanmıştır. Buffum ve ark.nın (2006) müziğin anjiyografiden önce bireylerin anksiyete düzeyi, kan basıncı, nabız ve solunumları üzerine etkisini araştırdıkla- r1 çalışmada, yalnız işlem süresince $15 \mathrm{dk}$ boyunca müzik dinleyen bireylerin durumluluk anksiyete puan ortalaması 38.57'den 35.2'ye düşmüş ve nabız sayısı da azalmıştır. ${ }^{[4]}$

Chlan ve ark. (2000) tarafindan yapılan bir çalışmada müzik terapisinin fleksibl sigmoidoskopi yapilan hastalardaki anksiyete, rahatsızlik ve memnuniyete olan etkisi incelenmiş, sonuçta müzik grubundaki hastaların daha az anksiyete ve rahatsızlık duydukları belirlenmiştir. ${ }^{[36]}$ Salmore ve Nelson (2000) ayaktan gastrointestinal endoskopi için gelen hastalarda işlem öncesinde uygulanan gevşeme teknikleri ve müziğin anksiyeteye etkisini incelemiş ve deney grubundakilerin anksiyete seviyelerinin daha düşük olduğunu bildirmişlerdir. [37] Uedo ve ark. (2004) kolonoskopi hastalarına dinletilen müziğin kortizol seviyesine olan etkisini incelemiş ve müziğin korku, stres ve kortizol salınımındaki değişiklikleri azalttığını bildirmişlerdir. ${ }^{[38]}$

Chan ve ark. (2003) müziğin kolonoskopi yapilan hastaların ağrı ve anksiyete düzeyine olan etkisini inceledikleri çalışmada, müzik dinletilen grubunun ağrı ve anksiyete düzeyini, müzik dinletilmeyen gruba göre düşük bulmuşlar ve aradaki farkın istatistiksel olarak anlamlı olduğunu ifade etmişlerdir. [39] İşkey'in bildirdiğgine göre müziğin kalp hastalarında anksiyete düzeyine etkisini inceleyen bir çalışmada; Cunningham (1985) 12'si ME, 12'si diğer kalp problemleri olan 24 hasta grubuna 37 dakikalık karışık klasik müzik dinletilerek bireylerin anksiyete düzeyine etkisini incelemiş ve sonunda müzik dinleyen bireylerde istatistiksel olarak önemli fakat klinik olarak önemsiz değişimler olduğunu belirtmiştir. ${ }^{[11]}$

Akut ME tanısı alan 80 hastanın örnekleme alındığı deneysel bir çalışmada, müzik ve gevşeme yöntemleri uygulanan deney grubundaki bireylerde anksiyete ve stresin azaldığ 1 saptanmıştır. ${ }^{[40]} \mathrm{Bu}$ bulgular, işlemden $30 \mathrm{dk}$ önce müzik eşliğinde yapılan PGE uygulamasının bireylerin anksiyete düzeyini ileri düzeyde azaltmada etkili olduğunu göstermektedir.

Bireylerin uygulama öncesi sürekli kayg1 puan ortalamaları arasında istatistiksel açıdan anlamlı bir fark bulunmamışken, uygulama sonrası sürekli kaygı puan ortalamaları arasında istatistiksel açıdan anlamlı bir fark bulunmuştur (Tablo 5).

Süreklilik kayg1 ölçeği; bireyin içinde bulunduğu durum ve koşullardan bağımsız olarak, genellikle kendini nasıl hissettiğini belirler. Spielberger ve ark. (1985) süreklilik ve durumluluk anksiyete puanları arasında ilişki olduğunu, süreklilik anksiyete düzeyi yüksek bireylerin durumluluk anksiyete düzeylerinin de yüksek olduğunu belirtmişlerdir. ${ }^{[41]}$

Sürekli kayg1 düzeyi bireyin sadece mevcut durumundan değil, yaşam şekli, kişilik özelliği gibi koşullardan da etkilenir. Durumluluk-süreklilik kayg1 kuramında ileri sürülen görüşlerde de; durumluluk kaygının anjiyografi ve PTKA gibi stresli bir yaşam olayında değişebileceği, buna karşın bir kişilik özelliği olarak kabul edilen sürekli kaygının değişmeyeceği vurgulanmaktadır. ${ }^{[41]}$ 


\section{Araştırmanın Sınırlılıkları}

Özellikle invaziv girişim öncesinde hasta odalarında bir ile altı hastanın olması nedeniyle hastaya işlem öncesi uygulanan formlarin doldurulması sirasinda zaman zaman odada gürültünün olması, çalışmanın yapıldığı kurumda genel olarak hasta yoğunluğunun fazla olması, KAG ve PTKA olacak bireylerle diğer kalp hastalarının bir arada olması, bu araştırmanın yalnızca DEÜ hastanesi kardiyoloji kliniğinde yapıdığı için diğer hastanelerde aynı girişim uygulanan hastalara genellenememesi, araştırmacı tarafindan uygulama öncesi ve sonrası uygulanan ölçeklere araştırmacının kör olmaması araştırmanın sınırlılıkları içindedir.

\section{Sonuç}

Koroner anjiyografi ve perkütan transluminal koroner anjiyoplasti işlemi öncesi kardiyoloji servisinde müzik eşliğinde uygulanan PGE'nin bireylerin anksiyete düzeylerini belirgin düzeyde azaltması nedeniyle müzik dinleme eşliğinde PGE uygulamasının kardiyoloji servisi rutinleri içinde yer almasının sağlanması, bu amaçla kardiyoloji servisinde primer uygulatıcılar olan hemşirelerin sorumluluk alması teşvik edilmelidir.

\section{Araştırma Fonu}

Bu çalışma, Adnan Menderes Üniversitesi Bilimsel Araştırma Projesi kapsamında ASYO-12007 proje kodu ile desteklenmiştir, teşekkürlerimizi sunarız.

\section{Kaynaklar}

1. Perkütan ve valvüler girişimler hemşirelik bakım klavuzu. Türk Kardiyoloji Derneği (www.tkfd.org.tr. Online). 2004:6.

2. Çelik Ş, Özen A. Koroner anjiyoplasti ve intra koroner stent uygulanan hastaların bakımı. Anadolu Hemşirelik ve Sağlık Bilimleri Dergisi 2010;13:2.

3. Doering LV, Imperial-Perez F, Monsein S, Esmailian F. Preoperative and postoperative predictors early and delayed extubation after coronary artery bypass surgery. American Journal of Critical Care 1998;7:1:37-45.

4. Buffum MD, Sasso C, Lanier E, Yelen M, et al. A music intervention to reduce anxiety before vascular angioraphy procedures. Journal of Vascular Nursing 2006;24:68-73.

5. Gallagher R, Trotter R, Donoghue J. Preprocedural concerns and anxiety assessment in patients undergoing coronary angiography and percutaneous coronary interventions. European Journal of Cardiovascular Nursing 2010;9:38-44.

6. Agvu KK, Okoyeb JJ. The effect of music on the anxiety levels of patients under going hysterosalpingography. Journal of Advantage Nursing 2006;1-4.

7. Uyar M, Akın Korhan E. The effect of music therapy on pain and anxiety in intensive care patients. Agri 2011;23:139-46.

8. Hindistan $S$, Nural N. Miyokard enfarktüsünde kadın ve erkek arasındaki farklııılar. Maltepe Üniversitesi Hemşirelik Bilim ve Sanatı Dergisi 2010;3:1.

9. Bradt J, Dileo C. Music for stress and anxiety reduction in coronary heart disease patients. Cochrane Database Syst Rev 2009;2:15.

10. Yıldırım NK. Konsültasyon liyezon psikiyatrisi hemşireliği. İstanbul Üniversitesi Tıp Fakültesi Psikiyatri Anabilim Dalı Konsültasyon Liyezon Psikiyatrisi Bilim Dalı (www.acibademhemsirelik.com) Erişim Tarihi: 23.02.2012.
11. İşkey M. Anjiografi işlemi öncesi ve işlem sırasında müzik dinlemenin bireylerin anksiyete düzeyi ve yaşam bulgularına etkisi. [Yayınlanmamış yüksek lisans tezi] Sivas: Cumhuriyet Üniversitesi Sağlık Bilimleri Enstitüsü; 2005.

12. Türk Psikologlar Derneği Progresif Kas Gevşeme Egzersizi CD'si.

13. Öner N. Durumluluk ve Sürekli Kaygı Envanterinin Türk Toplumunda Güvenilirliği ve Geçerliliği. [Yayınlanmamış doçentlik tezi] Ankara: Hacettepe Üniversitesi Sağlık Bilimleri Enstitüsü; 1997.

14. Wong HL, Lopez-Nahas V, Molassiotis A. Effects of music therapy on anxiety in ventilator-dependent patients. Heart Lung 2001;30:376-87.

15. Voss JA, Good M, Yates B, Baun MM, et al. Sedative music reduces anxiety and pain during chair rest after open-heart surgery. Pain 2004;112:197203.

16. Fitzsimons D, Parahoo K, Richardson SG, Stringer M. Patient anxiety while on a waiting list for coronary artery bypass surgery: a qualitative and quantitative analysis. Heart Lung 2003;32:23-31.

17. Gürsoy A. Ameliyat öncesi hastaların kaygı düzeyleri ve kaygıya neden olabilecek etmenlerin belirlenmesi. Hemşirelikte Araştırma Dergisi 2001;1:23-9.

18. Grene JA. Anxiety Disorders. Ed: B.S. Johnson, Psyhiatric-Mental Health Nursing Adaptation and Growth. Philadelphia: Lippincott Company; 2000; s. 453.

19. Türkiye İstatistik Kurumu 2013 www.tuik.gov.tr/Erişim Tarihi: 27.06.2014.

20. Bal V. Şok dalgaları ile taş kırma (Ekstracorporeal shock wave lithotripsyESWL) İşleminde Ağrı ve Anksiyete Düzeyi Üzerine Müziğin Etkisi. [Yayınlanmamış yüksek lisans tezi] Ankara: Genel Kurmay Başkanlığı Gülhane Askeri Tıp Akademisi Sağlık Bilimleri Enstitüsü; 2002.

21. López-Cepero Andrada JM, Amaya Vidal A, Castro Aguilar-Tablada T, García Reina I, et al. Anxiety during the performance of colonoscopies: modification using music therapy. Eur J Gastroenterol Hepatol 2004;16:1381-6.

22. Ferguson SL, Voll KV. Burn pain and anxiety: the use of music relaxation during rehabilitation. J Burn Care Rehabil 2004;25:8-14.

23. Akdağ A. Açık kalp ameliyatı geçiren hastalarda ameliyat öncesi ve sonrası anksiyete ve depresyon düzeylerinin karşılaştırmalı incelenmesi. [Yayınlanmamış yüksek lisans tezi] İstanbul: İstanbul Üniversitesi Sağlık Bilimleri Enstitüsü; 2001.

24. Dereli N. İlk kez kalıcı pacemaker yerleştirilen hastalara uygulanan programlanmış eğitimin hastanın anksiyete düzeyine olan etkisinin incelenmesi. [Yayınlanmamış doktora tezi] İzmir: Ege Üniversitesi Sağlık Bilimleri Enstitüsü; 1992.

25. Günaydın N, Oflaz F. Planlı ameliyat olacak hastaların anksiyete düzeylerinin incelenmesi. GATA Bülteni 1998;40:6-10.

26. Koca A. Açık kalp ameliyatı öncesi hasta eğitiminin anksiyete düzeyine etkisi. [Yayınlanmamış yüksek lisans tezi] İstanbul: İstanbul Üniversitesi Sağlık Bilimleri Enstitüsü; 1998.

27. Güneş P. Açık kalp ameliyati olan hastaları taburculuk öncesi bilgilendirmenin anksiyete düzeyine etkisi. [Yayınlanmamış yüksek lisans tezi] Sivas: Cumhuriyet Üniversitesi Sağlık Bilimleri Enstitüsü; 2001.

28. Uzun S, Vural H, Uzun M, Yokusoglu M. State and trait anxiety levels before coronary angiography. J Clin Nurs 2008;17:602-7.

29. Qasimi TB. Endoskopi işlemi uygulanacak hastaların işlem öncesi anksiyete düzeyleri ve bunu etkileyen faktörler. [Yayınlanmamış yüksek lisans tezi] İstanbul: İstanbul Üniversitesi Sağlık Bilimleri Enstitüsü; 2007.

30. Gökdoğan F. Endoskopi öncesi hastalarda oluşan anksiyeteye eğitimin etkisinin ölçülmesi ve değerlendirilmesi. [Yayınlanmamış yüksek lisans tezi] İstanbul: İstanbul Üniversitesi Sağlık Bilimleri Enstitüsü; 1989.

31. White JM. Effects of relaxing music on cardiac autonomic balance and anxiety after acute myocardial infarction. Am J Crit Care 1999;8:220-30.

32. Kuğuoğlu S. Ağrı algısını etkileyen faktörler. İçinde: Eti Aslan F, editör. Ağrı doğası ve kontrolü. İstanbul: Avrupa Tıp Kitapçılık; 2006. s. 52-60.

33. Abrahamov D, Bhatnagar G, Goldman B. Cerrahi ne zaman endikedir? Editörler: Soltoski PR, Karamaoukian HL, Salerno TA. Çeviri Editörü: Erentug V, Polat A. Kalp cerrahisi sırları. İstanbul: Nobel Tıp Kitabevi; 2006. s. 82-7. 
34. Salmon P. The reduction of anxiety in surgical patients: an important nursing task or the medicalization of preparatory worry? Int J Nurs Stud 1993;30:323-30.

35. Ferrer C. Ben enerjiyim. 3. Baskı. İstanbul: Arion Yayınevi; 2001. s. 125-38, 149-66.

36. Chlan L, Evans D, Greenleaf $M$, Walker J. Effects of a single music therapy intervention on anxiety, discomfort, satisfaction, and compliance with screening guidelines in outpatients undergoing flexible sigmoidoscopy. Gastroenterol Nurs 2000;23:148-56.

37. Salmore RG, Nelson JP. The effect of preprocedure teaching, relaxation instruction, and music on anxiety as measured by blood pressures in an outpatient gastrointestinal endoscopy laboratory. Gastroenterol Nurs
2000;23:102-10.

38. Uedo $\mathrm{N}$, Ishikawa $\mathrm{H}$, Morimoto $\mathrm{K}$, Ishihara $\mathrm{R}$, et al. Reduction in salivary cortisol level by music therapy during colonoscopic examination. Hepatogastroenterology 2004;51:451-3.

39. Chan YM, Lee PW, Ng TY, Ngan HY, et al. The use of music to reduce anxiety for patients undergoing colposcopy: a randomized trial. Gynecol Oncol 2003;91:213-7.

40. Kim H, Garvin BJ, Moser DK. Stress during mechanical ventilation: Benefit of having concrete objective information before cardiac surgery. American Journal of Critical Care 1999;8:118-27.

41. Spielberger CD, Gorusch RL, Lushene RE. State-trait anxiety inventory. Consulting Psychologists Press, 1970. 